\title{
The Development of Type 1 (Insulin-Dependent) Diabetes Mellitus: Two Contrasting Presentations
}

\author{
T.J.Orchard ${ }^{1}$, D.J. Becker ${ }^{2}$, R. W. Atchison"3, R. E. LaPorte', D. K. Wagener' ${ }^{1}$, B. S. Rabin ${ }^{4}$, L. H. Kuller ${ }^{1}$ \\ and A. L. Drash ${ }^{2}$ \\ Departments of ${ }^{1}$ Epidemiology, ${ }^{2}$ Pediatrics, ${ }^{3}$ Infectious Diseases and Microbiology and ${ }^{4}$ Immunopathology, University of Pittsburgh, Pittsburgh, \\ USA
}

\begin{abstract}
Summary. Genetic, immunological and viral factors have been implicated in pathogenesis of Type 1 diabetes mellitus. The development of Type 1 diabetes in two siblings of patients with Type 1 diabetes studied as part of a large epidemiological study, is described. One case, a 13-year-old male not sharing either HLA haplotype with his diabetic sister, had virtually normal glucose tolerance 80 days before symptomatic presentation. He showed serological evidence of infection by Coxsackie $\mathrm{CB}_{4}$ (at diagnosis) and influenza $\mathrm{A}$ virus (soon after diagnosis). The other case, a 15-year-old male, had impaired glucose tolerance for over 500 days (i.e., since the diagnosis of
\end{abstract}

diabetes in his HLA-identical brother) before symptomatic presentation which was not associated with serological evidence of acute viral infection. The former case was negative for islet cell antibody (cytoplasmic) when first seen though positive at diagnosis, while the latter was positive throughout. These two cases suggest contrasting interactions of the main pathogenetic factors associated with Type 1 diabetes.

Key words: Type 1 diabetes, aetiology, HLA type, virus, islet cell, autoantibody.
To study the development of Type 1 (insulin-dependent) diabetes mellitus and examine putative aetiological factors, we have untertaken a large, family-based study. This involves longitudinal follow-up of siblings of new cases of Type 1 diabetes who are at increased risk for developing the disease [1]. In this report, we present data on two contrasting cases where Type 1 diabetes has developed in siblings of patients studied both before and at diagnosis.

\section{Subject and Methods}

\section{Subjects}

All cases of Type 1 diabetes (and their families) presenting at Children's Hospital from 1 February 1979 onwards are eligible for participation in our study. In addition, we have, for comparison, recruited a number of single and multiple-case families where the index diabetic child was diagnosed at Children's Hospital of Pittsburgh before this date. To date, three individuals recruited into this study have subsequently developed Type 1 diabetes. The first case, not reported here, is a 31-year-old parent, while the other two patients are white boys, aged 13 (patient 1 ) and 15 years (patient 2).

On recruitment and after obtaining informed consent, we obtain blood from all new cases and their first degree relatives for the following determinations: viral serology (on two occasions during admission), HLA typing (A, B, C and, recently, DR loci), glycosylated hae- moglobin $\left(\mathrm{HbA}_{1}\right)$, serum autoantibodies and immunoglobulins. In addition, the parents (aged < 30 years) and siblings undergo a 4 -h oral glucose tolerance test with measurements of plasma glucose, insulin, growth hormone and glucagon [2]. Those with impaired glucose tolerance [3] have a repeat test 3-6 months later. All siblings, however, are seen annually when further serum is obtained for storage and fasting blood glucose estimation.

\section{Immunology}

HLA typing was performed using Terasaki microtitre trays (University of California, Los Angeles, California, USA) and the standard Amos procedure [4]. Immunoglobulin concentrations were determined using the Beckman ICS Analyzer (Beckman Instruments, Fullerton, California, USA). Autoantibodies were determined by indirect immunofluorescence on unfixed tissue (adrenal, gastric parietal, and smooth muscle), or Bouin's fixed tissue (pancreatic islet cell cytoplasmic), and by passive haemagglutination for thyroid microsomes.

\section{Virology}

The procedure of Schmidt [5] was modified for the determination of neutralizing antibody titres of single or paired sera against Coxsackie B prototype strains B1-B6. Haemagglutination-inhibition tests were run against influenza $\mathrm{A} / \mathrm{Brazi} / 11 / 78$ (H1N1), A/Bangkok/1/79 (H3N2) and B/Hong Kong/5/72 strains. In addition, immunofluorescent tests for human IgG serum antibodies to each of the Coxsackie B strains were performed [6]. (Fuller details available from RWA). 
Table 1. Family histories and HLA types

\begin{tabular}{cll}
\hline & Patient 1 & Patient 2 \\
\hline Family history & $\begin{array}{l}\text { Father, diagnosed } \\
\text { 17 years previously } \\
\text { at age 15 years } \\
\text { Sister, diagnosed } \\
\text { 6 years previously } \\
\text { at age 8 years }\end{array}$ & $\begin{array}{l}\text { Brother, diagnosed } \\
\text { 17 months } \\
\text { previously } \\
\text { at age 6 years }\end{array}$ \\
& A33/34 B14 DR1 & A1 B8 DR4 \\
HLA type of & A9 B8 DR3 & A2 B15 CW3 DR4 \\
patient & Sister & Brother \\
HLA type of & A 30/31 B13 DR7 & A1 B8 DR4 \\
other family \\
members with \\
Type 1 diabetes & A10 B7 DR8 & A2 B15 CW3 DR4 \\
& Father & \\
& A9 B8 DR3 & \\
& A10 B7 DR8 & \\
\hline
\end{tabular}

\section{Metabolic Studies}

The oral glucose tolerance test was performed as previously described [2]. At each sampling, plasma was also analyzed for insulin and growth hormone using a modification of the method of Herbert et al. [7], and for glucagon [8]. $\mathrm{HbA}_{1}$ was determined on the $-30 \mathrm{~min}$ sample and is expressed as a percentage of total haemoglobin as measured by microcolumn chromatography (Isolab, Akron, Ohio, USA) in a water bath at $22^{\circ} \mathrm{C}$. Coefficients of variation for $\mathrm{HbA}_{1}$ are $2 \%$ intra-assay and $6 \%$ interassay. C-peptide was measured using the Novo C-peptide kit (Novo Research Institute, Bagsvaerd, Denmark) at diagnosis of Type 1 diabetes and at subsequent clinic visits.

\section{Results}

\section{Family History}

Patient 1 has both a father and sister with Type 1 diabetes diagnosed many years previously, while patient 2 has a brother whose Type 1 diabetes was diagnosed only 17 months earlier (Table 1). The sharing of HLA haplotypes between the patients in these families also differs (Table 1). Patient 2 is HLA identical to his diabetic brother, while patient 1 is totally HLA non-identical to his diabetic sister.

\section{Clinical Presentation and Metabolic Data}

Patient 1: Ten weeks before diagnosis patient 1 underwent an oral glucose tolerance test (Table 2). Although classed as normal [3] the fasting, 30 and $60 \mathrm{~min}$ plasma glucose values were above our mean +2 SD for similarly aged siblings [2]. Basal concentrations of growth hormone and glucagon were normal but there was no glucagon suppression by glucose.

At presentation he gave a 2-day history of polyuria and mild hyperphagia during which he had 2\%-5\% glycosuria with no ketones. Six days before admission he had suffered abdominal cramps, diarrhoea and headache. On admission he has not acutely ill and there were no signs of weight loss or active infection. He had glycosuria but no ketonuria or biochemical acidosis. Blood glucose was $15.3 \mathrm{mmol} / 1$ on a random sample with $\mathrm{HbA}_{1}$ of $9.4 \%$ (normal range $4.9 \%-7.4 \%$ ). Full blood count was normal except for a mild lymphocytosis. The C-peptide concentration was $0.23 \mathrm{pmol} / \mathrm{ml}$. Eight months later the fasting serum C-peptide concentration was $0.1 \mathrm{pmol} / \mathrm{ml}$, and doubled after stimulation by a meal.

Patient 2: Seventeen months before diagnosis of Type 1 diabetes (i, e., at the time of his brother's diagnosis), patient 2 showed impaired glucose tolerance (Table 2). This was associated with normal plasma insulin concentrations for his age, but a delayed peak at $2 \mathrm{~h}$ and sustained elevations of plasma insulin. Plasma glucagon concentrations were high and showed late suppression. Growth hormone suppressed normally. Three months later there was further impairment of glucose tolerance with lower plasma insulin concentrations and a paradoxical rise of plasma glucagon. Growth hormone was again normally suppressed.

He presented with a 1-week history of increased appetite and a 4-day history of polyuria. During this period glycosuria varied from $0 \%$ to $5 \%$, with no ketonuria. He also gave a history of midmorning hunger for 2 years, a $1 \mathrm{~kg}$ weight loss over the previous month, and an influenza-like illness 2 weeks before admission.

On admission, he was marginally underweight for his height with a blood glucose of $6.1 \mathrm{mmol} / 1$ (fasting) and $12.6 \mathrm{mmol} / 14 \mathrm{~h}$ post-prandial. His full blood count was normal. A C-peptide level 1 month after admission was $0.04 \mathrm{pmol} / \mathrm{ml}$.

\section{Immunology}

Patient 1 was negative for all five autoantibodies when first seen, though at diagnosis 10 weeks later he was positive for islet cell (cytoplasmic) and smooth muscle antibodies. Immunoglobulins were normal throughout.

Patient 2 was positive for islet cell (cytoplasmic) antibodies and had a raised serum IgG concentration $(3080 \mathrm{mmol} / 1)$ when first seen. He remained islet-cellantibody-positive throughout follow-up, while his immunoglobulins returned to normal within 1 month.

\section{Virology}

Four serum specimens were analyzed from patient 1 (Table 3). He had had a significant neutralizing antibody conversion against Coxsackie B4 and possibly B3 viruses by the time of diagnosis. Indirect immunofluorescence test results on the first two sera available paralleled the neutralizing antibody results, i. e. IgG antibody against $\mathrm{CB} 4$ and $\mathrm{CB} 3$ rose from $1 / 2$ to $1 / 32$ and from $1 / 2$ to $1 / 8$, respectively. Tests on serum taken at diagnosis and on day 31 post-diagnosis showed a significant eightfold rise in influenza A antibody titre (Table 3 ). 
Table 2. Plasma glucose, insulin, growth hormone and glucagon concentrations during oral glucose tolerance testing

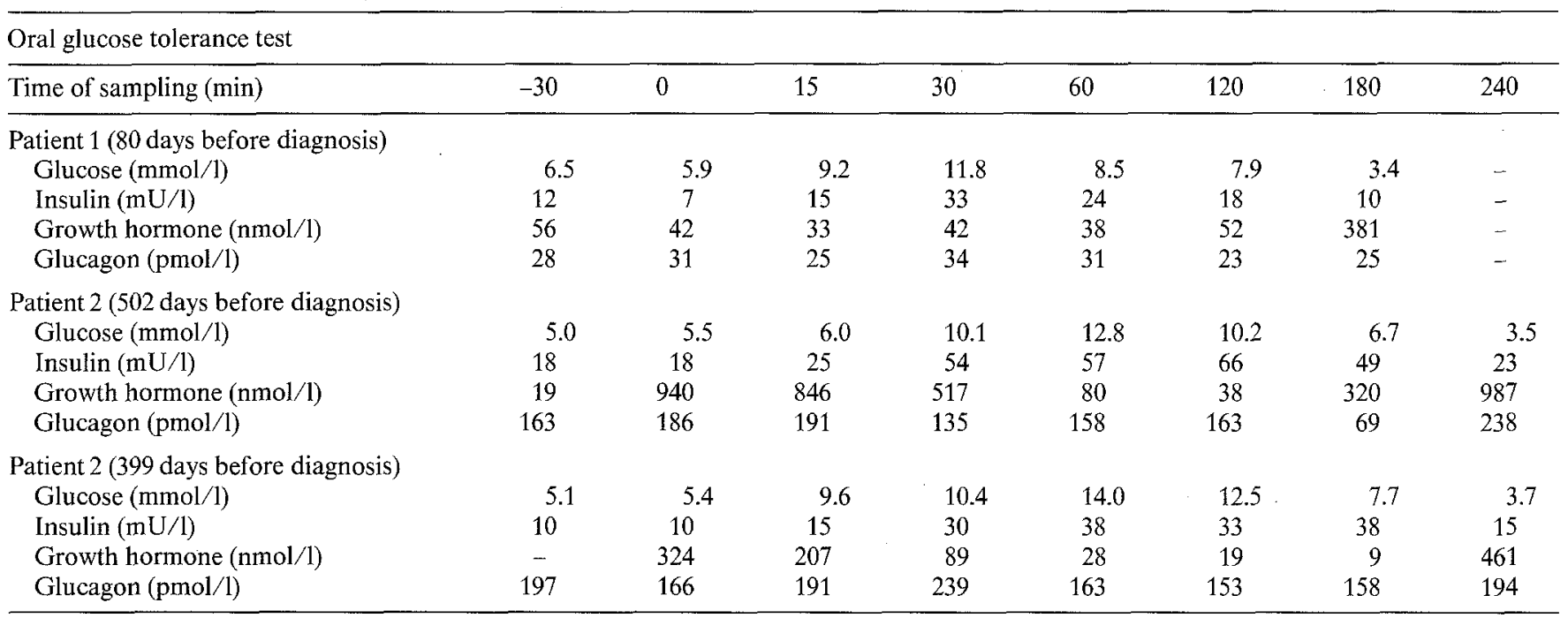

Table 3. Significant Coxsackie virus type B (CB) and influenza type A serological responses

\begin{tabular}{|c|c|c|c|}
\hline & \multicolumn{3}{|c|}{ Virus antibody titres ${ }^{1}$} \\
\hline & $\begin{array}{l}\text { Coxsackie } \\
\text { virus }\end{array}$ & Serotypes $^{2}$ & $\begin{array}{l}\text { Influenza } \\
\text { type }^{3}\end{array}$ \\
\hline Patient 1 & CB3 & CB4 & $\begin{array}{l}\text { A/Bang- } \\
\text { kok/1/79 }\end{array}$ \\
\hline 80 days before diagnosis & 10 & 10 & 10 \\
\hline At diagnosis & 20 & 80 & 10 \\
\hline 30 days after diagnosis & 10 & 80 & 80 \\
\hline 234 days after diagnosis & 10 & 80 & 80 \\
\hline Patient 2 & $\mathrm{CB} 2$ & CB4 & A \\
\hline 502 days before diagnosis & 40 & 10 & 80 \\
\hline 97 days before diagnosis & 20 & 10 & 20 \\
\hline Diagnosis & 10 & 10 & 40 \\
\hline 25 days after diagnosis & 10 & 10 & 10 \\
\hline
\end{tabular}

1 Antibody titres expressed as reciprocal of twofold dilution series beginning at $1 / 10 ;{ }^{2}$ Neutralizing antibody; ${ }^{3}$ Haemagglutination-inhibition

Two other members of the family showed similar evidence of an influenza A infection at this time.

Four sera were also tested from patient 2 (Table 3 ) and showed evidence of past influenza $A$ (and $B$, not shown) infections. There was no serological evidence for current Coxsackie B virus infection at diagnosis although neutralizing antibody present in the first serum available showed a previous B2 infection to have occurred. By immunofluorescence testing, his first serum sample showed the presence of viral IgG antibody to Coxsackie B3 and a rise in IgG antibody titre to Coxsackie $B 2$ from $\leqslant 1: 4$ to $1: 16$ between days 502 and 97 before diagnosis. Patient 2's diabetic brother, at his own diagnosis, showed evidence of a past Coxsackie B4 infection followed shortly by a B5 infection (eightfold rise in neutralizing titres) and high titres to influenza $A$ and $\mathrm{B}$ at diagnosis.

\section{Discussion}

These two case histories demonstrate contrasting patterns of development of Type 1 diabetes. In patient 2, an HLA-identical sibling of the index case, Type 1 diabetes was preceded by a 17 -month period of impaired glucose tolerance documented from the time of the diagnosis of his brother's diabetes and only equivocal evidence of viral infection. In contrast patient 1 , a non-HLA-identical sibling of a diabetic child diagnosed many years previously, presented with good evidence of both Coxsackie B4 and influenza infection at or soon after diagnosis. He had normal glucose tolerance only 2 months previously. Furthermore, while patient 1 was negative for islet cell (cytoplasmic) antibody until diagnosis, patient 2 was persistently islet-cell-antibody-positive since he was first seen. This suggests that in one case (patient 2) the pathogenetic mechanism may have been one of prolonged autoimmune-associated deterioration of islet Bcell function, as recently suggested by Gorsuch et al. [9] in a genetically high risk sibling. Such siblings are reported in some studies to have glucose tolerance abnormalities $[10,11]$. The other case (patient 1) may have developed Type 1 diabetes in association with an acute viral infection but with a less clear genetic and autoimmune background.

It should be noted that these two cases may not be completely different. For example, the impaired glucose tolerance and autoimmune process in patient 2 might have been precipitated by a viral infection 17 months or more before the development of symptomatic diabetes. In addition, some of the prediagnosis plasma glucose values of patient 1 could be considered by other criteria to be abnormal [2].

The difficulty in interpretation of these viral and metabolic studies underscores the complexities of investigating the aetiology of Type 1 diabetes. The viral data from patient 1 suggest that viral infection (possibly 
multiple) may be involved. However, the role of the islet cell autoantibodies must still be in question because in both cases islet cell destruction may have already started by the time that the islet cell antibodies were detect$\mathrm{ed}$, and thus be the result of such destruction and not its cause [12]. More intensive and frequent testing (including viral isolation studies at diagnosis) of many high risk individuals (e.g., siblings) will be needed to resolve these problems.

Acknowledgements. This study was partially funded by USPHS grants, AM-24021, 5K01 AM-0885-02 and the Renzichausen Trust.

\section{References}

1. Wagener DK, Kuller LH, Orchard TJ, LaPorte RE, Rabin B, Drash AL (1982) Pittsburgh diabetes mellitus study: secondary attack rates in families with insulin-dependent diabetes mellitus. Am J Epidemiol 115: 868-878

2. Orchard TJ, Becker DJ, Kuller LH, Wagener DK, LaPorte RE, Drash AL (1982) Age and sex variations in glucose tolerance and insulin responses: parallels with cardiovascular risk. J Chronic Dis 35: $123-132$

3. National Diabetes Data Group (1979) Classification and diagnosis of diabetes mellitus and other categories of glucose intolerance. Diabetes 28: 1039-1057

4. Amos B (1974) Manual of tissue typing techniques. Washington D.C. Department of Health, Education and Welfare, Publication No. (NIH) 77-545: 23-26

5. Schmidt NJ (1969) Tissue culture techniques for diagnostic virolo- gy. In: Lennette EH, Schmidt NJ (eds) Diagnostic procedures for viral and rickettsial diseases, 4th edn. American Public Health Association, New York, pp 79-178

6. Henle W, Henle GE (1979) Epstein-Barr virus specific diagnostic tests in infectious mononucleosis. Hum Pathol 5: 551-565

7. Herbert V, Lau KS, Gottlieb CW (1965) Coated charcoal immunoassay of insulin. J Clin Endocrinol 25: 1375-1384

8. Harris V, Falcona GR, Unger RH (1979) Glucagon. In: Jaffee BM, Behrman HR (eds) Methods of hormone immunoassay, 2nd edn. Academic Press, New York, pp 643-656

9. Gorsuch AN, Lister J, Dean BM, Spencer KM, McNally JM, Bottazzo GF, Cudworth AG (1981) Evidence for a long prediabetic period in Type 1 (insulin-dependent) diabetes mellitus. Lancet 2: 1363-1365

10. Orchard TJ, Rabin B, Wagener DK, Salas M, Banks M, Drash AL (1980) Metabolic features associated with specific HLA types (B8, B15, B18) and sharing of haplotypes with a diabetic sibling. Diabetes 29 (Suppl 2): 326 (Abstract)

11. Ginsberg-Fellner F, Dobersen MJ, Witt ME, Rayfield EJ, Rubinstein P, Notkins AL (1982) HLA antigens, cytoplasmic islet cell antibodies, and carbohydrate tolerance in families of children with insulin-dependent diabetes mellitus. Diabetes 31: 292-298

12. Nerup J, Lernmark A (1981) Autoimmunity in insulin-dependent diabetes mellitus. Am J Med 70: 135-141

Received: 29 July 1982

and in revised form: 6 June 1983

Dr. T.J.Orchard

Department of Epidemiology

Graduate School of Public Health

130 DeSoto Street

Pittsburgh, PA 15261

USA 